Article

\title{
Investigation of the Weld Properties of Dissimilar S32205 Duplex Stainless Steel with AISI 304 Steel Joints Produced by Arc Stud Welding
}

\author{
Aziz Barış Başyiğit ${ }^{1, *}$ and Adem Kurt ${ }^{2}$ \\ 1 Faculty of Engineering, Metallurgical and Material Engineering Department, Kırıkkale University, \\ 71450 Kirıkkale, Turkey \\ 2 Faculty of Technology, Metallurgical and Material Engineering Department, Gazi University, 06500 Ankara, \\ Turkey; ademkurt@gazi.edu.tr \\ * Correspondence: abbasyigit@kku.edu.tr; Tel.: +90-318-357-4242
}

Academic Editors: Adem Kurt, Necip Fazil Yilmaz and Halil Ibrahim Kurt Received: 28 November 2016; Accepted: 23 February 2017; Published: 1 March 2017

\begin{abstract}
UNS S32205 duplex stainless steel plates with a thickness of $3 \mathrm{~mm}$ are arc stud welded by M8 $\times 40 \mathrm{~mm}$ AISI 304 austenitic stainless steel studs with constant stud lifts in order to investigate the effects of welding arc voltages on mechanical and microstructural behaviors of the joints. As the welding arc voltage increases starting from $140 \mathrm{~V}$, the tensile strength of the weldment also increases but the higher arc values results in more spatters around the weld seam up to $180 \mathrm{~V}$. Conversely, the lower arc voltages causes poor tensile strength values to weldments. Tensile tests proved that all of the samples are split from each other in the welding zone but deformation occurs in duplex plates during the tensile testing of weldments so that the elongation values are not practically notable. The satisfactory tensile strength and bending values are determined by applying 180 volts of welding arc voltage according to ISO 14555 standard. Peak values of micro hardness occurred in weld metal most probably as a consequence of increasing heat input decreasing the delta ferrite ratios. As the arc voltage increases, the width of the heat affected zone increases. Coarsening of delta-ferrite and austenite grains was observed in the weld metal peak temperature zone but it especially becomes visible closer to the duplex side in all samples. The large voids and unwelded zones up to approximately $1 \mathrm{~mm}$ by length are observed by macro-structure inspections. Besides visual tests and micro-structural surveys; bending and microhardness tests with radiographic inspection were applied to samples for maintaining the correct welding parameters in obtaining well-qualified weldments of these two distinct groups of stainless steel materials.
\end{abstract}

Keywords: arc stud welding; duplex stainless steels; austenitic stainless steels

\section{Introduction}

Duplex stainless steels are widely used in fields that require both corrosion and mechanical properties such as bridges, pipe-lines, chemical tanks, marine, and petro-chemical applications. They have replaced austenitic alloys in many applications where stress corrosion, cracking, and pitting corrosion are the basic topics. As compared to the austenitic types, duplex stainless steels exhibit some important advantages of higher mechanical strength and superior corrosion resistance properties but the economic considerations have to be taken into account that duplex alloys are more expensive than austenitic types because of their production difficulties [1,2].

Duplex alloys contain approximately half austenitic and half ferritic microstructure so the balanced structure gains better resistance to chloride and stress corrosion cracking rather than single austenitic structure [1-6]. 
Duplex stainless steels form various kinds of detrimental precipitates due to the temperatures that they experience. Hence, some precautions should be taken into account while they are welded or heat treated. Besides, as the cooling rate of weldment or heat-treated duplex alloy increases, the delta-ferrite ratio increases and the amount of austenitic phase structure also decreases [1-3,6-8]. The delta-ferrite content of these alloys also depends on temperatures that encountered in their thermal treatments $[1,2,9]$.

As austenitic stainless steels are cheaper than duplex stainless steels, they can be substituted for duplex alloys mainly for economic considerations. Thus in this work; austenitic AISI 304 stainless steel is displaced for S32205 duplex stainless alloy due to economic viewpoints. In many industrial applications, these two distinct alloy groups are joined by each other with numerous kinds of well-known arc welding techniques such as TIG, MIG, and covered electrode welding. However, in this practice, owing to fast and practical way of application, arc stud welding process is preferred. The arc stud welding process has been used as an alternative metal-fastening method since the 1940s [3]. Arc stud welding technique is widely used in basic applications such as bolts, nuts, pins, furniture chassis, household appliances, automobiles, structural applications, and heat insulation parts. Stud arc welding, also known as arc stud welding, is a commonly used method for joining a metal stud, or fastener, to a metal work piece as schematically shown in Figure 1.

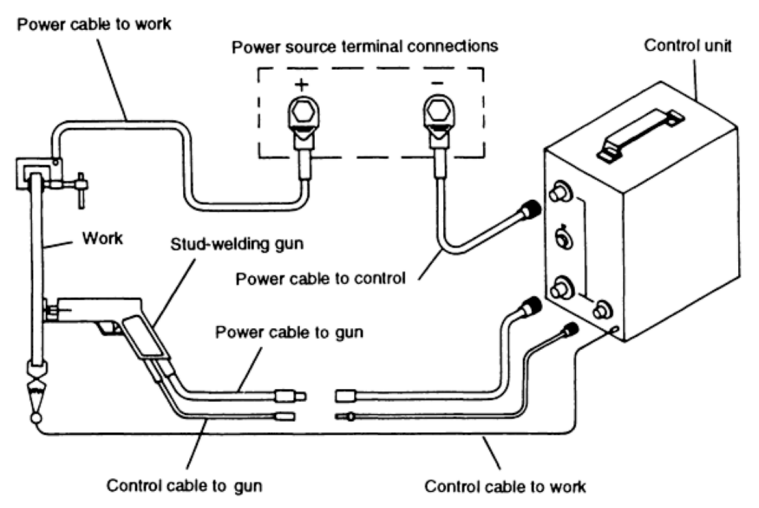

Figure 1. The schematic view of arc stud welding [3].

The basic equipment used for stud arc welding consists of a portable gun which holds the stud in position during the welding process to create the proper arc length and joining pressure and a power source which regulates the arc voltage and connecting cables. The other items that are needed to weld the work piece are the studs themselves [3].

The stud, which acts as an electrode, is inserted into a chuck at the end of the gun and positioned against the work piece. Next, the gun trigger is depressed, which starts the weld cycle by discharging the energy stored in capacitors in which the tip of the stud melts almost instantly. The arc melts the end of the stud and also a portion of the work piece together simultaneously as in Figure 2 [3].

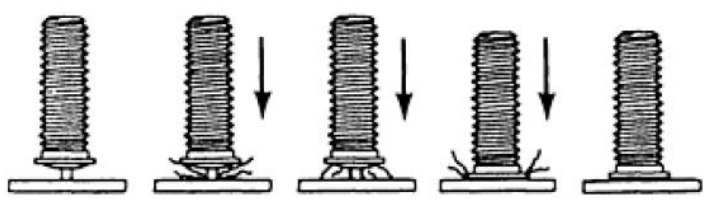

Figure 2. Stages of arc stud welding [3].

This investigation basically focuses on the arc stud welded joint qualification according to ISO 14555 standard for obtaining satisfactory mechanical properties even though the cheaper austenitic stud is preferred instead of more expensive duplex stainless steel ones. 


\section{Materials and Methods}

Experimental study is based on M8 $\times 40 \mathrm{~mm}$ AISI 304 austenitic stainless steel studs and S32205 duplex stainless steel plates with a thickness of $3 \mathrm{~mm}$. Spectral analysis results of studs and plates are given in Table 1.

Table 1. Spectral analysis of studs and plates (values by wt. \%).

\begin{tabular}{cccccccccccc}
\hline Material & $\mathbf{C}$ & $\mathbf{S i}$ & $\mathbf{M n}$ & $\mathbf{C r}$ & $\mathbf{N i}$ & $\mathbf{M o}$ & $\mathbf{P}$ & $\mathbf{S}$ & $\mathbf{N}$ & $\mathbf{F e}$ & Others \\
\hline Studs (304) & 0.038 & 0.290 & 1.570 & 18.90 & 10.83 & 0.297 & 0.022 & 0.0005 & 0.092 & 67.3 & 0.66 \\
Plates (S32205) & 0.016 & 0.340 & 0.832 & 24.95 & 6.638 & 3.511 & 0.015 & 0.0004 & 0.306 & 62.7 & 0.68 \\
\hline
\end{tabular}

S32205 duplex stainless plates were machined about $45 \times 145 \mathrm{~mm}$ in dimensions for arc stud welding. M8 × $40 \mathrm{~mm} 304$ studs and duplex plates are given in Figure 3 .

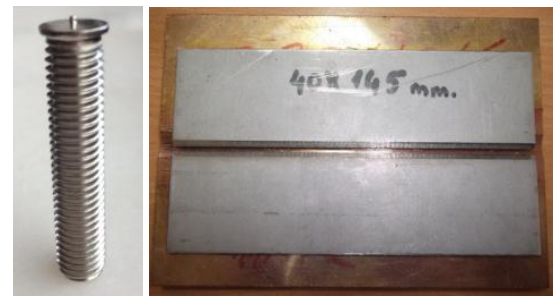

Figure 3. AISI 304 austenitic studs with S32205 Duplex plates.

Arc stud welding operation is applied with constant stud lifts of $7 \mathrm{~mm}$. Stud lift is the distance between the stud tip and the work piece surface with the stud lifting mechanism in position and as activated.

Three different arc voltages are applied for observing the effects of arc voltage on weldment properties. The capacitor discharge arc stud welding device is capable of $200 \mathrm{~V}$ maximum voltage with its welding gun.

Constant stud lift is adjusted in welding although arc voltage is altered. While the stud gun is connected to DC $(-)$ polarity, duplex plates were connected to $(+)$ polarity. Arc stud welding parameters are shown in Table 2.

Table 2. Welding parameters of arc stud welding.

\begin{tabular}{ccc}
\hline Parameter & Arc Voltage (V) & Stud Lift (mm) \\
\hline 1 & 140 & 7 \\
2 & 160 & 7 \\
3 & 180 & 7 \\
\hline
\end{tabular}

The two samples per welding parameter are arc stud welded by three different arc voltages. Welded samples of $140 \mathrm{~V}, 160 \mathrm{~V}$, and $180 \mathrm{~V}$ are shown in Figure 4 as examples. All samples exhibit straight 90 degrees horizontally on plates after welding operation.

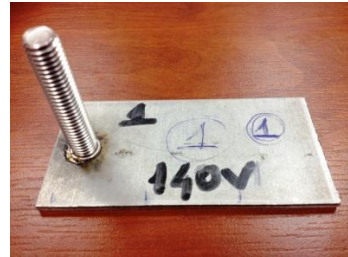

(a)

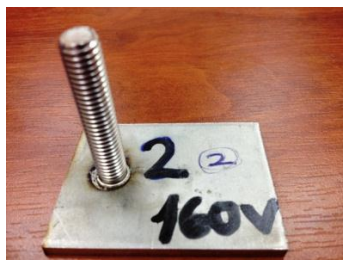

(b)

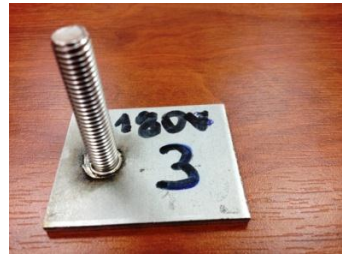

(c)

Figure 4. Arc stud welded joints: (a) Sample 1-140 V; (b) Sample 2-160 V; (c) Sample 3-180 V. 


\section{Results}

\subsection{Microstructural Survey of Unwelded (Raw) Duplex Plates and Austenitic Studs}

Microstructural images of unwelded (raw) S32205 duplex stainless steel plate are shown in Figure 5 below. The rolling direction of S32205 duplex steel is obviously visible.

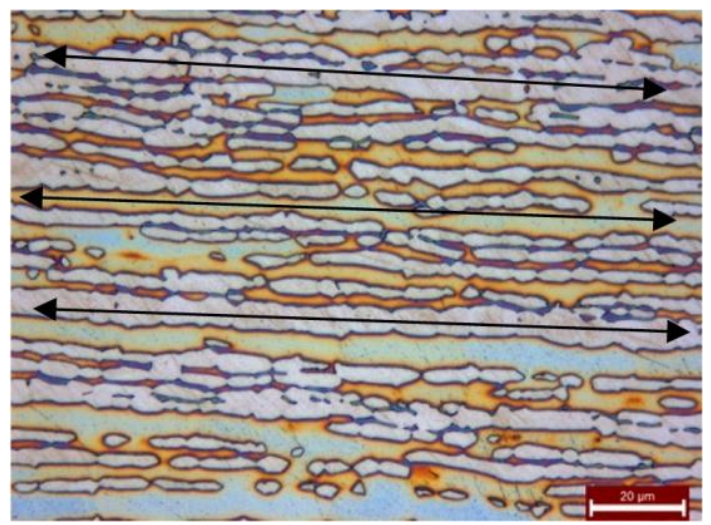

(a)

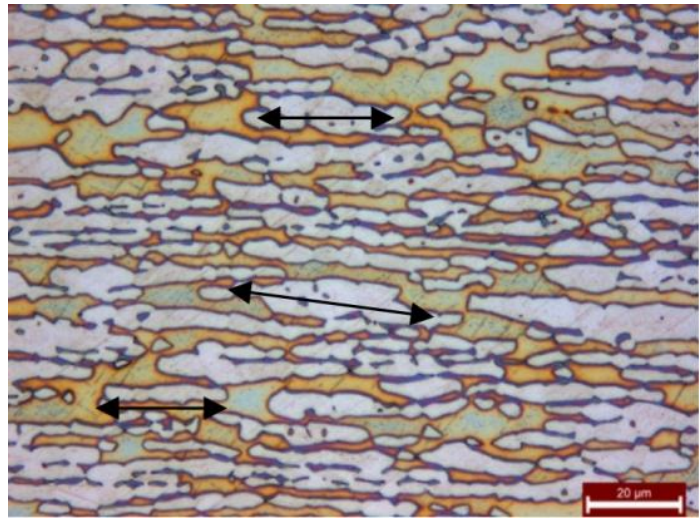

(b)

Figure 5. Longitudinal (a) and transverse (b) micrographs of raw S32205 duplex stainless steel plates $(20 \mu \mathrm{m}$ scale- $500 \times)$.

The brownish phase is delta-ferrite and the white phase is austenite in Figure 5. The duplex structure consists of $54 \%$ delta ferrite and $46 \%$ austenite according to microstructural image analysis in ASTM E562 [10], ASTM E1245 [11], and ASTM E112 [12] as given in Figure 6.
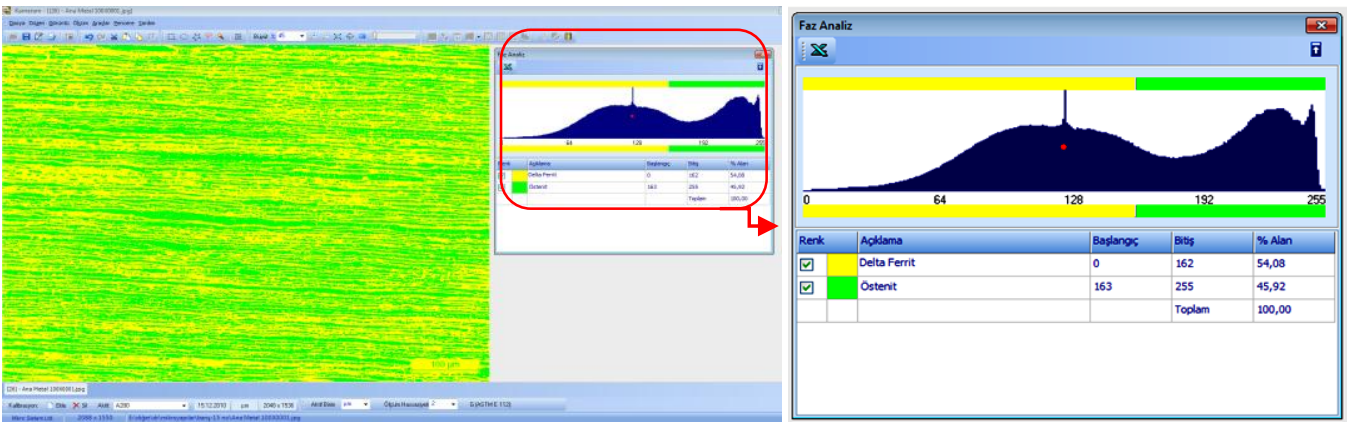

Figure 6. Image analysis of raw (unwelded) stainless steels.

Besides the image analysis, the magnetic phase testing with Ferrite-tester gauge due to the magnetic delta ferrite phase is also applied on duplex stainless steel plates to verify the phase analysis results according to EN ISO 17655 [13] and EN ISO 8249 [14] from six individual measures that are given in Table 3. The arithmetic mean values of six magnetic testing results are estimated according to EN ISO 8249 standard. 
Table 3. Magnetic phase testing results according to EN ISO 17655 and EN ISO 8249.

\begin{tabular}{ccc}
\hline $\begin{array}{c}\text { The Ferritetester-ISO 8249 and } \\
\text { ANSI/AWS A4.2-Results by EN } \\
\text { ISO 17655 Standard }\end{array}$ & Mean Value & $\begin{array}{c}\text { Standard } \\
\text { Deviation }\end{array}$ \\
\hline 53.8 & & \\
53.6 & & \\
53.1 & 54 & 1.1125046816381 \\
54.9 & & \\
54.1 & & \\
56.2 & & \\
\hline
\end{tabular}

The duplex phase structure includes approximately $54 \%$ delta-ferrite and $46 \%$ austenite by magnetic testing results. The microstructure of entirely austenitic (100\%) stud is shown in Figure 7. Dominant white phase is austenite. The stud is originally forged by screw production method by the stud manufacturer as visible in Figure 7.

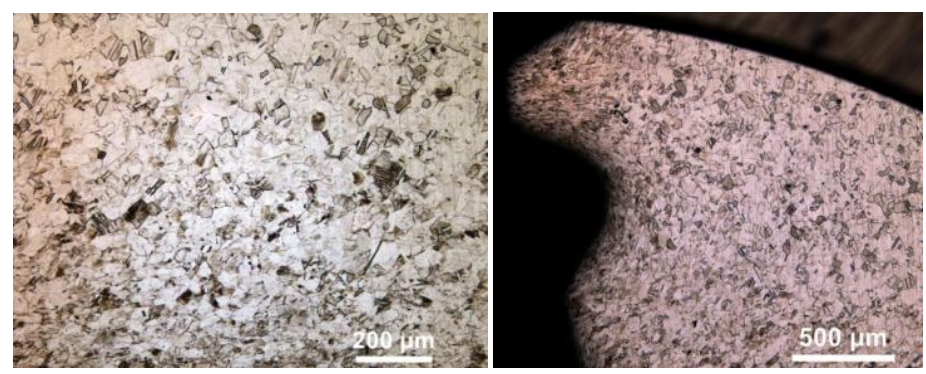

Figure 7. Completely austenitic microstructure of studs.

\subsection{Visual Inspection of Arc Stud Welded Duplex Plates and Austenitic Studs}

Visual survey is made according to ISO 14555 [15] in order to display the general view of weldments by corresponding with pattern images. The standard covers the spatter types to be accepted or rejected in tables. If the welding parameters are appropriately adjusted, then the view of surrounding welding region also fits with the accepted illustrations in standard.

Images of Samples $1(140 \mathrm{~V}), 2(160 \mathrm{~V}), 3(180 \mathrm{~V})$ are given in Figure 8 according to ISO 14555.
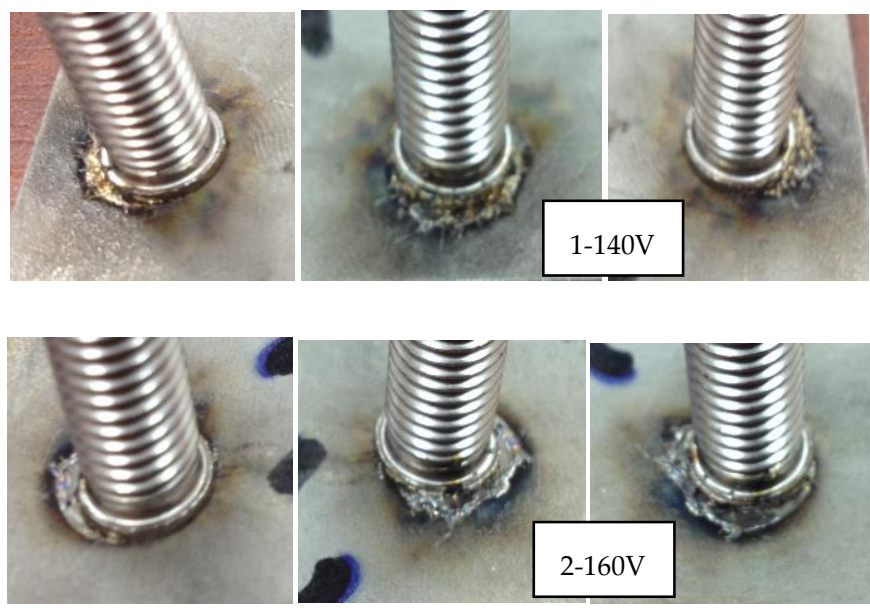

Figure 8. Cont. 

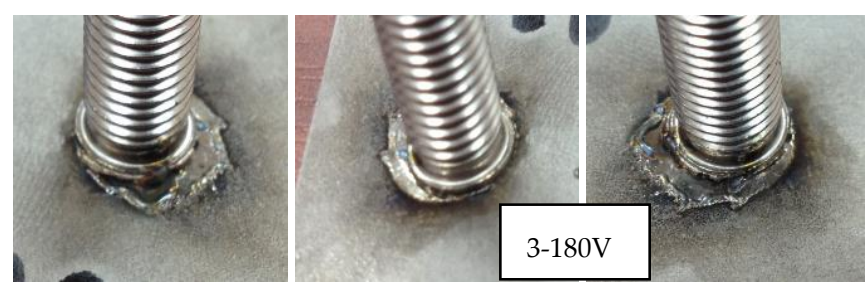

Figure 8. Visual inspection images of samples: 1-140 V, 2-160 V, and 3-180 V according to ISO 14555.

Whether changing the welding arc voltage, there are no considerable differences about spatter distribution noted around the welding zones as seen in Figure 8. The types of spatters are identified in ISO 14555 standard. There is also no major difference of spatter types between each samples. As compared to the ISO 14555 standard, there are no extreme spatters around the welding zone to be noticed as a huge defect.

\subsection{Macro-Structural Inspection of Weldments}

Macro-structural examination is applied for detecting the welding macro defects. The large voids and unwelded zones approximately up to $1 \mathrm{~mm}$ in length become visible as seen in Figure 9.

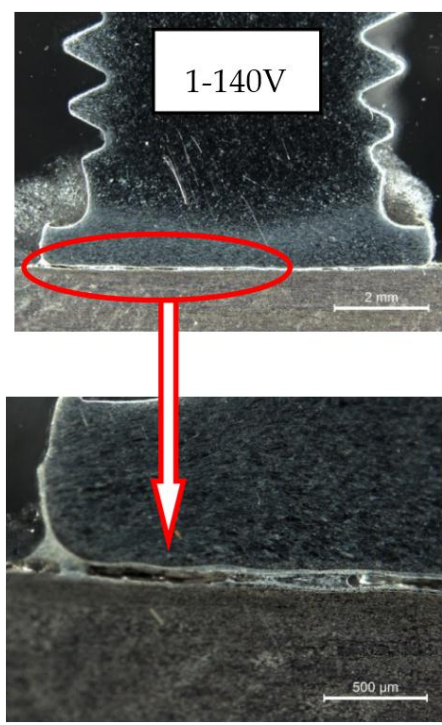

(a)

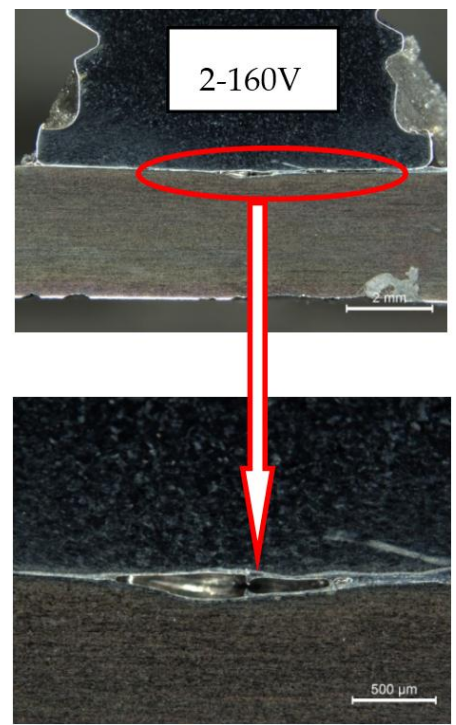

(b)

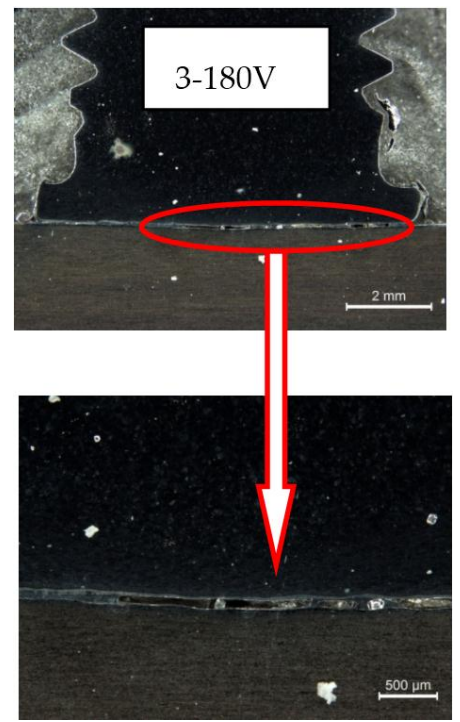

(c)

Figure 9. Unwelded zones and voids in macro-structure images of samples: (a) 1-140 V, (b) 2-160 V, and (c) 3-180 V.

There have been no major differences in macro structures but, as the welding arc voltage increases starting from $140 \mathrm{~V}$, the quantities of voids and total surface areas of unwelded zones slightly decreases.

\subsection{Micro-Structural Inspection of Weldments}

Microstructures of arc stud welded Sample 1 (140 V), Sample 2 (160 V), and Sample 3 (180 V) are given in Figure 10.

Duplex structure consists of austenite and delta-ferrite in the matrix but closer to the heat affected zone, delta ferrite ratio increases. Increasing the cooling rate increases the delta-ferrite ratio in duplex stainless steels $[1-4,16]$. 
While getting closer to heat affected zones of weldments, harder equaxed delta-ferrite and austenite grains along the ferritic-austenitic matrix are observed adjacent to the fusion boundary in all three welding conditions.

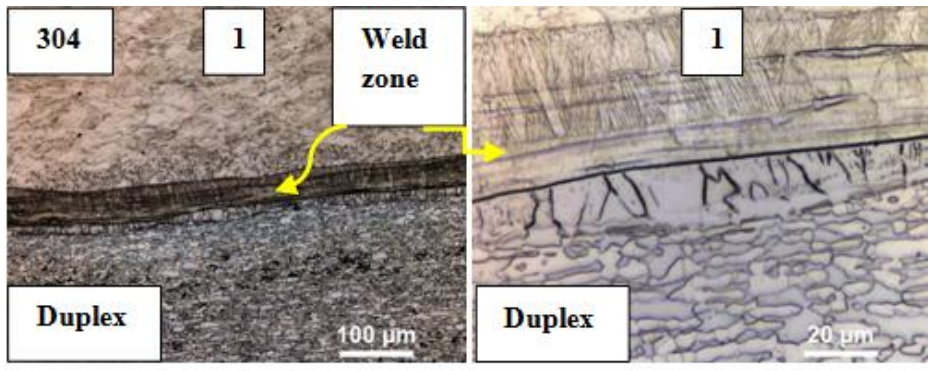

(a)

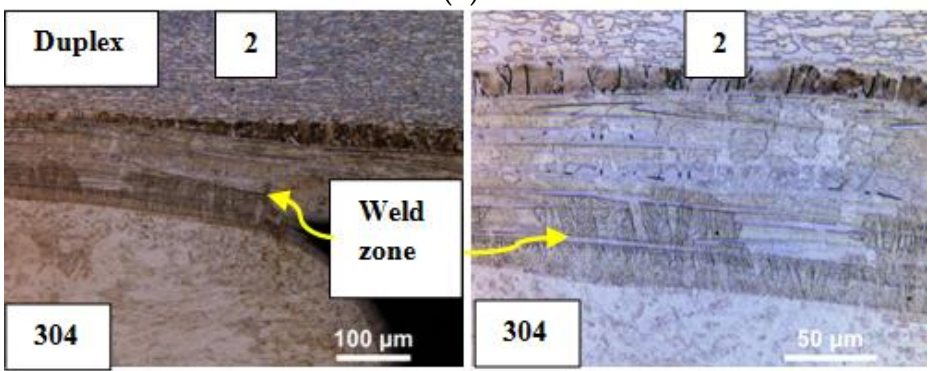

(b)

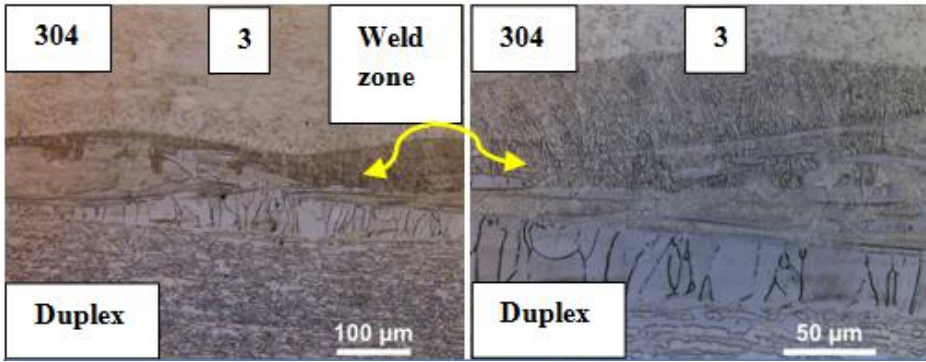

(c)

Figure 10. Microstructures of weldments (a) 1-140 V, (b) 2-160 V, (c) 3-180 V. Darker lines in the middle of microstructures indicate the weld center areas.

Furthermore, as the arc voltage increases the width of the heat affected zone also increases. Besides, coarsening of delta-ferrite and austenite grains was observed in the weld metal peak temperature zones but especially in the areas that adjacent to the duplex side in all samples.

\subsection{Microhardness Testing}

Micro Vickers test is applied on welded samples and unwelded (raw) materials concerning the heat affected zones and weld metal. The microhardness test is managed by a computerized micro Vickers instrument with $1200 \times$ magnification. Maximum recorded values of hardness test results are given in Table 4.

Table 4. Micro-Vickers hardness of 140 V, 160 V, 180 V welded samples.

\begin{tabular}{|c|c|c|c|c|c|c|c|}
\hline \multirow{2}{*}{$\begin{array}{c}\text { Welded } \\
\text { Sample }\end{array}$} & \multirow{2}{*}{$\begin{array}{c}\text { AISI } 304 \\
\text { Studs }\end{array}$} & \multicolumn{2}{|c|}{$\begin{array}{l}\text { Heat Effected Zone } \\
\text { Close to AISI } 304\end{array}$} & \multirow{2}{*}{$\begin{array}{c}\begin{array}{c}\text { Weld Metal } \\
\left(\mathbf{H V}_{\mathbf{0 . 0 5}}\right)\end{array} \\
432\end{array}$} & \multicolumn{2}{|c|}{$\begin{array}{l}\text { Heat Effected Zone } \\
\text { Close to S32205 }\end{array}$} & \multirow{2}{*}{$\begin{array}{c}\begin{array}{c}\text { S32205 } \\
\text { Plates }\end{array} \\
312\end{array}$} \\
\hline & & 312 & 303 & & 240 & 230 & \\
\hline $160 \mathrm{~V}$ & 230 & 317 & 312 & 371 & 312 & 303 & 312 \\
\hline $180 \mathrm{~V}$ & 230 & 285 & 294 & 358 & 278 & 278 & 312 \\
\hline
\end{tabular}


The screen images of the micro Vickers testing instrument is given in Figure 11 according to the values of Sample 1-140 V presented in Table 4 as examples. Micro Vickers hardness tests are applied directly onto the welding, heat effected, and uneffected zones as given in Figure 11.

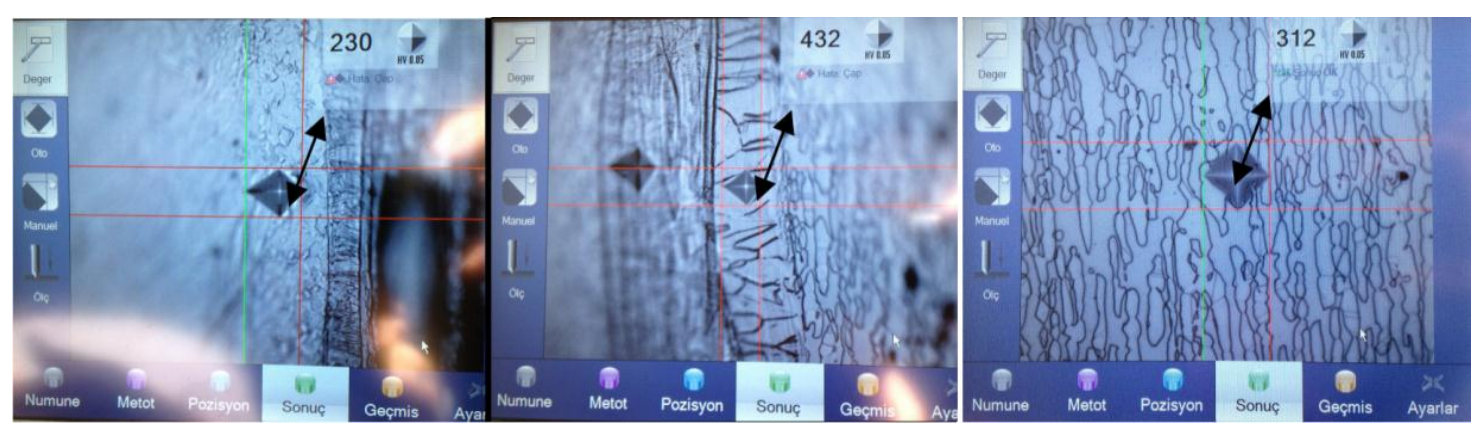

Figure 11. Micro Vickers hardness measurement screens of 1-140 V welded samples $(1200 \times)$.

Sample 1-140 V exposes the highest hardness values in comparison with Sample 2-160 V and Sample 3-180 V in consequence of decreasing arc voltage decreases the heat input and also increases the cooling rates of weldments. Sample 3 exhibits the least micro Vickers hardness values, most probably because of the increasing heat input decreases the amount of delta-ferrite ratios in the weld metal zone [1].

\subsection{Tensile and Bend Testing of Weldments}

Tensile and bending testing is conducted according to ISO 14555 standard by using a tensile and bending test apparatus as shown in Figure 12.
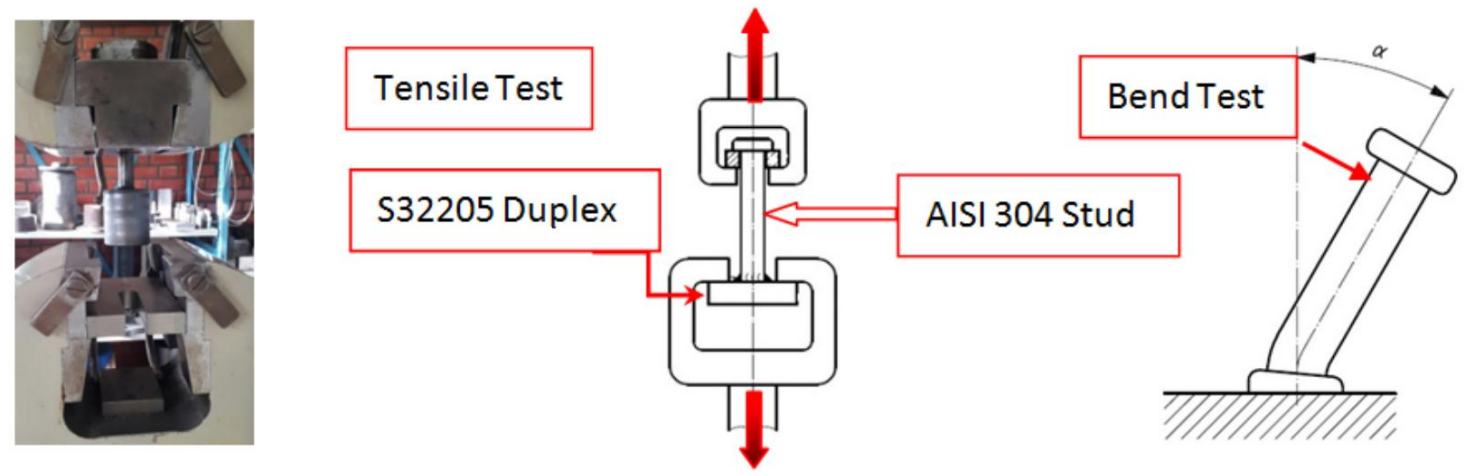

Figure 12. Tensile and bending test apparatus according to ISO 14555 standard.

The average values of tensile and bending test results are given in Table 5 . Test samples were bent by a convenient $\mathrm{M} 8$ fitted lever until $30^{\circ}$ was obtained.

Sample 1-140 V presented the worst performance on the bending test. Sample 1-140 V split away from the duplex plate by even in $9^{\circ}$ effective bending angle from the vertical axis.

Furthermore, Sample 2-160 V bent by $31^{\circ}$. Therefore, according to ISO 14555 standard, $30^{\circ}$ is adequate for qualifying in test.

Finally Sample 3-180 V exhibited the best bending angle of $57^{\circ}$ even without splitting. 
Table 5. Tensile and bending test results.

\begin{tabular}{|c|c|c|c|c|c|c|}
\hline \multirow{2}{*}{$\begin{array}{l}\text { Welded } \\
\text { Sample }\end{array}$} & \multicolumn{2}{|c|}{$\begin{array}{c}\text { Tensile Strength }{ }^{1} \\
\left(\mathrm{~N} / \mathrm{mm}^{2}\right)\end{array}$} & \multirow{2}{*}{$\begin{array}{c}\text { Tensile Strength }^{1} \\
\left(\mathrm{~N} / \mathrm{mm}^{2}\right) \\
\text { Mean Values }\end{array}$} & \multirow{2}{*}{ Remarks } & \multirow{2}{*}{$\begin{array}{c}\text { Bending Mean } \\
\text { Value }^{2} \\
\text { (in degrees) }\end{array}$} & \multirow{2}{*}{ Remarks } \\
\hline & 1 & 2 & & & & \\
\hline $1(140 \mathrm{~V})$ & 360.65 & 237.158 & 298.904 & $\begin{array}{l}\text { Fracture in weld } \\
\text { zone, duplex plate is } \\
\text { slightly bent by } \\
\text { tensile test }\end{array}$ & 9 & $\begin{array}{l}\text { Failed by } \\
\text { bending tests }\end{array}$ \\
\hline $2(160 \mathrm{~V})$ & 483.60 & 407.377 & 445.488 & $\begin{array}{l}\text { Fracture in weld } \\
\text { zone, duplex plate is } \\
\text { bent by tensile test }\end{array}$ & 31 & $\begin{array}{c}\text { Split and } \\
\text { cracked by } \\
\text { bending more } \\
\text { than } 31^{\circ} \text { Passed }\end{array}$ \\
\hline $3(180 \mathrm{~V})$ & 443.169 & 442.076 & 442.6225 & $\begin{array}{l}\text { Fracture in weld } \\
\text { zone, duplex plate is } \\
\text { extremely bent by } \\
\text { tensile test }\end{array}$ & 57 & $\begin{array}{l}\text { No split, no } \\
\text { cracks up to } 57^{\circ} \\
\text { Passed }\end{array}$ \\
\hline
\end{tabular}

${ }^{1} 515 \mathrm{~N} / \mathrm{mm}^{2}$ for AISI 304 and $620 \mathrm{~N} / \mathrm{mm}^{2}$ for S32205 steels as minimum, ${ }^{2}$ bending value $>30^{\circ}$, ISO 14555 .

Bending angles are determined by a protractor and an angle-meter like in Figure 13.

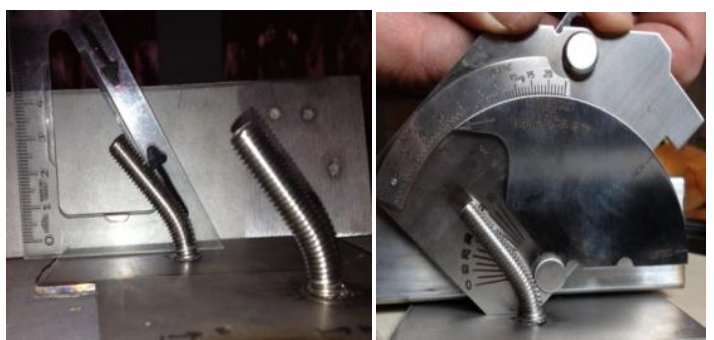

Figure 13. Bending angle determination of samples.

Macro images were also taken from the split zones after the tensile tests for clearly viewing the split zones of studs. The curvature of $1(140 \mathrm{~V}), 2(160 \mathrm{~V}), 3(180 \mathrm{~V})$ welded plates are also given in Figure 14. The curvature degree of plates proves the satisfactory tensile strength of a weldment that reaches close to the austenitic studs' strength values.
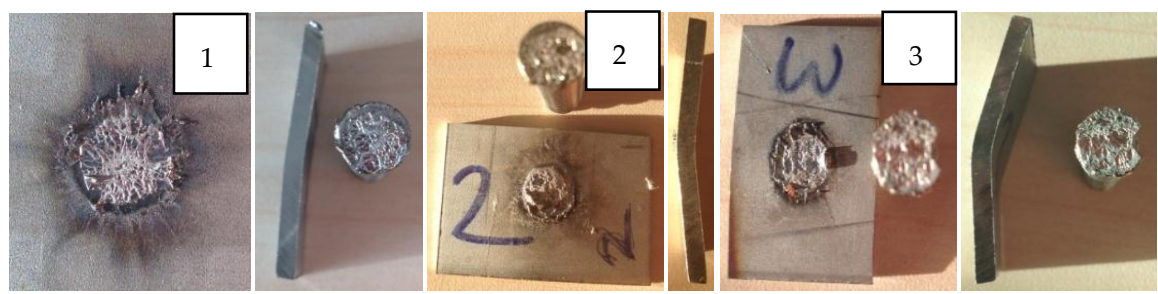

Figure 14. Macro images of split studs (1-140 V, 2-160 V, 3-180 V) and curvature of plates as examples.

Split weldment macro images point out that the surface morphology is like pitch-set in appearance. Pore diameter in the weld zone after tensile test generally does not exceed $0.5 \mathrm{~mm}$ as indicated in ISO 14555. However, there a few larger pores diameter up to $1 \mathrm{~mm}$ were observed, especially in $140 \mathrm{~V}$ and $160 \mathrm{~V}$ arc stud welded samples. Semi-fine grained microstructure is also observed in macro images.

\subsection{Radiographic Inspection of Weldments}

Besides tensile and bending tests, radiographic inspection was also applied to all samples. Radiographic images are shown in Figure 15. 


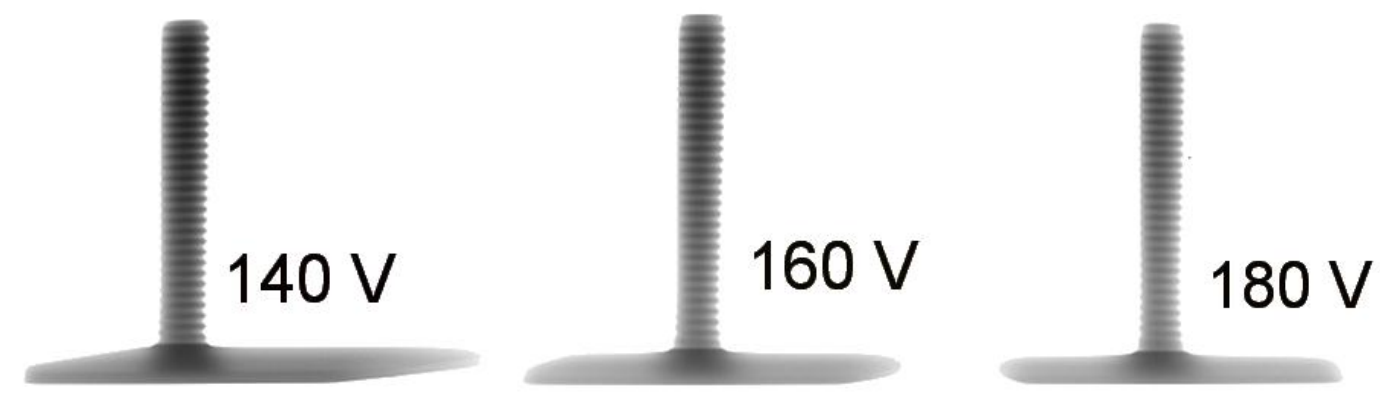

Figure 15. Radiographic inspection of $140 \mathrm{~V}, 160 \mathrm{~V}$, and $180 \mathrm{~V}$ welding voltage applied samples, $100 \mathrm{kV}$, $1200 \mu \mathrm{A}, 20 \mathrm{~s}, 50 \mathrm{~cm}$.

The welding split zones are unfortunately invisible to radiographic inspection, most likely as a consequence of very complex and thin structure of weldments. As it seems to be, no major cracks and huge defaults in welding zones of samples by radiographic inspection images.

\section{Discussion}

AISI 304 austenitic stainless steel can securely be substituted to be welded with more expensive S32205 duplex stainless steels by arc stud welding. However, as the corrosion resistance in chloride containing media is in question, it should be noted that austenitic alloys should not be preferred.

There are no major spatters detected around the welding zones to be noticed as a massive defect within any of the samples according to pattern images listed by ISO 14555.

The large voids and unwelded zones of up to approximately $1 \mathrm{~mm}$ in length are visible in the macrostructures.

As the welding arc voltage increases, the quantities of voids and total surface areas of unwelded zones decrease to a limit degree of $180 \mathrm{~V}$ encountered in macro images of weldments. Increasing welding arc voltage also increases the width of heat affected zones in microstructures.

Delta-ferrite and austenite grains closer to duplex sides were coarsened in the weld metal peak temperature zones in all samples.

Whether the heat input increases, micro Vickers hardness values decreases through the samples. Increasing cooling rates increases the delta ferrite ratios in balanced duplex microstructure.

All samples failed in the tensile tests as they were fractured from weld zones, but the strength of weldments is close to the AISI 304 austenitic stud tensile strength values. Furthermore, duplex stainless steel plates were all curved during the tensile tests.

Sample 3-180 V proved to have superior bending angle without cracking with a $57^{\circ}$ bending angle.

In spite of applying a comprehensive radiographic inspection, welding discontinuities such as voids, unwelded zones, and cracks cannot be easily determined by radiographic method. That is most likely because of the complex and thin geometric structure of studs and plates.

\section{Conclusions}

Austenitic stainless steel groups can be safely joined to duplex grades by arc stud welding processes like multiple choices of other welding techniques, but if aggressive corrosive media especially like chloride containing solutions are present, choice of the duplex series is inevitable.

Joining performance of austenitic studs with duplex plates by arc stud welding technique depends seriously on the welding arc voltage. Proper welding arc voltage values will safely maintain satisfactory joining quality.

Acknowledgments: The authors would like to express their gratitude to Gazi University Welding and Joining Technologies Research and Application Center for great laboratory supports.

Author Contributions: A.B.B. and A.K. conceived and designed the experiments; A.B.B. and A.K. performed the experiments; A.B.B. and A.K. analyzed the data; A.B.B. and A.K. wrote the paper. 
Conflicts of Interest: The authors declare no conflict of interest.

\section{References}

1. Lippold, J.C.; Kotecki, D.J. Welding Metallurgy and Weldability of Stainless Steels; John Wiley and Sons Inc.: Hoboken, NJ, USA, 2005; pp. 250-251.

2. Gunn, R.N. Duplex Stainless Steels Microstructures Properties and Applications; Abington Publishing: Cambridge, UK, 2005; pp. 24-76.

3. ASM Handbook Committee. ASM Metals Handbook Volume 6: Welding Brazing and Soldering; ASM International: Materials Park, OH, USA, 1993.

4. ASM Handbook Committee. ASM Metals Handbook Volume 9: Metallography and Microstructures of Stainless Steels and Maraging Steels; George, F., Vander, V., Eds.; ASM International: Materials Park, OH, USA, 2004.

5. ASM Handbook Committee. ASM Metals Handbook Volume 13A: Corrosion: Fundamentals, Testing, and Protection; Cramer, S.D., Covino, B.S., Eds.; ASM International: Materials Park, OH, USA, 2003.

6. Roberge, P.R. Handbook of Corrosion Engineering, Chapter 8 Materials Selection; Mc-Graw Hill Publications: New York City, NY, USA, 2000; pp. 717-730.

7. Kou, S. Welding Metallurgy; John Wiley and Sons Inc.: Hoboken, NJ, USA, 2003; p. 227.

8. Palmer, T.A.; Elmer, J.W.; Babu, S.S. Observations of Ferrite/Austenite Transformations in the Heat Affected Zone of 2205 Duplex Stainless Steel Spot Welds Using Time Re-solved X-Ray Diffraction. Mater. Sci. Eng. 2004, 374, 307-321. [CrossRef]

9. Tehovnik, F.; Arzensek, B.; Arh, B.; Skobir, D. Microstructure Evolution in SAF 2507 Super Duplex Stainless Steel. Mater. Technol. 2011, 45, 339-345.

10. ASTM E562-11. In Standard Test Method for Determining Volume Fraction for Systematic Manual Point Count; ASTM International: West Conshohocken, PA, USA, 2011.

11. ASTM E1245-03. In Standard Practice for Determining the Inclusion or Second phase Constituent of Metals by Automatic Image Analysis; ASTM International: West Conshohocken, PA, USA, 2008.

12. ASTM E112-13. In Standard Test Methods for Determining Average Grain Size; ASTM International: West Conshohocken, PA, USA, 2013.

13. TS EN ISO 17655. In Destructive Tests on Welds in Metallic Materials-Method for Taking Samples for Delta Ferrite Measurement; ISO: Geneva, Switzerland, 2004.

14. TS EN ISO 8249. In Welding-Determination of Ferrite Number (FN) in Austenitic and Duplex Stainless Steel Weld Materials; ISO: Geneva, Switzerland, 2000.

15. ISO 14555. In Welding-Arc Stud Welding of Metallic Materials, 2nd ed.; ISO: Geneva, Switzerland, 2006.

16. Zhang, W.; Debroy, T.; Palmer, T.A.; Elmer, J.W. Modeling of Ferrite Formation in a Duplex Stainless Steel Weld Considering Non-uniform Starting Microstructure. Acta Mater. 2005, 53, 4441-4453. [CrossRef]

(C) 2017 by the authors. Licensee MDPI, Basel, Switzerland. This article is an open access article distributed under the terms and conditions of the Creative Commons Attribution (CC BY) license (http:/ / creativecommons.org/licenses/by/4.0/). 